ANIMAL tests should be relied on to indicate whether a chemical will be carcinogenic in humans, says a trade union document on occupational cancers published last week.

"When it comes to the interpretation of test results" says the document "the UK guidelines fall far short of their US counterparts. It is stated in the US guidelines that a positive result in animal tests is to be accepted as evidence of human carcinogenicity. Not so in the UK guidelines, where it is stated that "extrapolation is a difficult procedure',".

Produced by Britain's half-million strong Association of Scientific Technical and Managerial Staffs, the report was launched at a press conference by ASTMS General Secretary, Clive Jenkins. "Too many of our members are dying"' he said. "Tens of thousands of new chemicals have been introduced to the workplace since the war. Companies have acted irresponsibly. We want exposure to carcinogens reduced to zero. We want a new approach in law.'”.

Sheila McKechnie, ASTMS Health and Safety Officer, said that her union "was not attempting to ban all chemicals". Of 7,000 or so chemicals that have been tested so far, says the report, "only 600-800 have shown any evidence of carcinogenicity".

Epidemiological studies - or 'body counts' as the report calls them - come too late: "keeping track of the effects of new (and existing) chemicals by observation of the effects on workers - if relied on exclusively - turns the work place into a giant laboratory for the conduct of an experiment in carcinogenesis. No trade union can accept this.

The evidence is that animal carcinogens are human carcinogens, says the report. "Even if subsequent research unearths some exceptions to this rule, it must be taken as a conservative regulatory principle, that is a principle erring on the side of safety. To refuse to accept the evidence of animal bioassays means, in practice, to insist on counting bodies as the only valid method of identifying carcinogens. This is the position usually adopted by industry - especially an industry threatened with the banning of some profitable commodity."

ASTMS is demanding a comprehensive licensing scheme for toxic substances. Under the scheme:

- Only potentially useful substances should be submitted for test.

- The tests should be carried out in public or independent laboratories and financed by a general levy on the industries supplying the substances.

- Only substances which pass these tests should be licensed for commercial use, subject to safeguards dictated by the results of the toxicity tests.

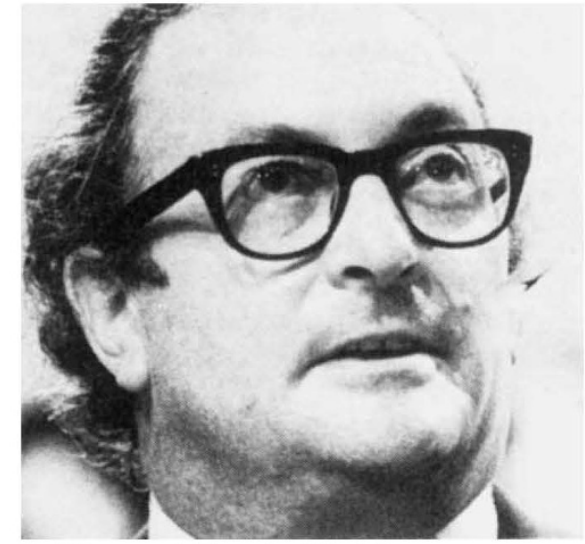

Jenkins: would love health strike

- All companies handling licensed substances should be compelled to keep comprehensive records.

The process of awarding compensation should also be completely overhauled, said Jenkins. "Some firms have internal compensation. We are urging our members not to accept it. One firm - I don't want to name it - went to a man on his death bed and persuaded him to accept the firm's compensation. He would have done much better in the courts."

ASTMS recommends that "occupational cancer' be recognised as a broad category of industrial disease, and that cancer victims should be automatically entitled to compensation if they can show they were exposed to a known carcinogen, or were involved in an occupation that clearly shows an elevated risk of cancer. The scheme could be funded by a specially flouted National Cancer Insurance scheme, drawing on both public funds and general levies on industry. "There is great sympathy in the Trades Union Council for our views"' said Jenkins.

Would ASTMS take strike action over this issue? "I'd love a strike over health" said Jenkins.

However, the US regulations urged by ASTMS are themselves under pressure, as reported in Nature (24 January, page 320). In the latest proposals of the US Occupational Safety and Health Administration, it is expected that the list of 'category 1' carcinogens (ones where scientific evidence of carcinogenicity is strong) will have only 150 chemicals, and only 10 of these a year will be selected for 'special attention'. US industry still feels the regulations to be too restrictive, while unions are attacking OSHA for lowering its sights.

At its press conference, ASTMS was attacked on the scientific basis of its report, which claims that $20-40 \%$ of cancers can be traced to occupational causes or synergisms. In particular two of its sources have been roundly attacked: Samuel Epstein's book, 'The Politics of Cancer', and a joint report of the US National Cancer Institute, National Institute of Environmental Health Sciences, and the National Institute for Occupational Safety and Health, titled 'Estimates of the fraction of cancer in the US related to occupational factors'.

However, said Sheila McKechnie, ASTMS did not want their recommendations to stand or fall on technicalities. If the proportion was $40 \%$ or $5 \%$ it was still too much.

So how will British industry respond? "We are trying to get unions involved in testing these chemicals, to make sure they are unbiased" said Sheila McKechnie. "Initially testing will have to be done in industry; but so far we have met no resistance from companies on the pre-testing of new chemicals. It's chemicals where companies are already deeply involved where there is a problem."

Robert Walgate

\title{
Coal produced electricity the cheapest, says US economist
}

AN American energy economics consultant who waged a successful environmental battle against the emissions of coal-fired power stations in the early 1970s argued last week that electricity produced from coal in the late 80 s will be cheaper than nuclear electricity. If he were right, breakeven would only occur in the UK if coal tripled in real price over the next eight years.

The consultant, Dr Charles Komanoff, presented his views at a joint session of the Parliamentary Liaison Group for Alternative Energy Strategies and the environmental group Green Alliance. (Parligaes is a rapidly growing association of MPs and others designed to provide a source of information in the House of Commons alternative to that of the national energy bodies in the case of electricity, largely the United Kingdom Atomic Energy Authority and the Central Electricity Generating Board.) Later, Komanoff gave evidence before the House Select Committee on Energy.

In both fora, Komanoff based his argument on an analysis of capital cost escalation in the 162 power plants built in 